\title{
The (Pregnant) Mouse Freed from the Gallows: A Ballad Parallel for the Conclusion of Manawydan fab Llŷr
}

\author{
Thomas D. Hill \& Kristen Mills
}

\begin{abstract}
In the concluding episode of the Third Branch of the Mabinogi, the Welsh nobleman Manawydan takes the (pregnant) mouse that he has captured to the magically significant site Gorsedd Arberth and prepares to hang her for theft, according to the law. As he prepares the gallows, various figures attempt to intervene until finally a 'bishop' redeems his transformed wife by disenchanting the land, freeing Manawydan's companions, and swearing not to take vengeance. We argue that this scene is strikingly similar to the famous ballad widely attested all over Europe, 'The Maid Freed from the Gallows', a parallel which not only illuminates this episode in the Mabinogi, but also suggests how the Welsh storyteller used traditional material in shaping these narratives.
\end{abstract}

\section{Introduction}

Some years ago in a review of Tom Peete Cross's Motif Index of Early Irish Literature, Kenneth H. Jackson wrote that folklorists sometimes seem unaware of medieval Celtic instances of motifs and 'international popular tales' that antedate many better known folkloric texts-Including both ballads and folktales-by centuries. ${ }^{1}$ In his book The International Popular Tale and Early Welsh Tradition Jackson illustrates this claim by pointing out a number of folkloric analogues to such medieval Welsh texts as Culhwch and Olwen and the tales that make up 'The Four Branches of the Mabinogi' (Jackson 1961). ${ }^{2}$ This line of research was later codified by Andrew Welsh who catalogued the traditional motifs in the Four Branches (Welsh 1988), and it is fair to say that in recent decades folkloristic and Celtic scholarship have become more fully integrated. For example, in an article that closely parallels our interests, Sarah Larratt Keefer elucidated some puzzling details in the Fourth Branch of the Mabinogi by means of comparison with the Scots ballad, 'The Great Selkie of Skule Skerry'. Her paper was well received and indeed anthologized in a Garland casebook (Keefer 1989, 1996). In this article we would like to follow out this line of 
research by comparing a specific episode in the Third Branch of the Mabinogi, Manawydan fab Llŷr, with another famous ballad that exists in a wide variety of versions (including eleven collected by F. J. Child in the nineteenth century), and which might almost better be described as a ballad family: ‘The Maid Freed from the Gallows' (Child no. 95).

The narrative pattern of Manawydan fab Llŷr is comparatively simple. At the beginning of the story, the Welsh lords Manawydan and Pryderi are comrades who have survived a cosmic battle in Ireland. In the battle, which occurred in the Second Branch of the Mabinogi, all of the Irish warriors and all but seven of the British ones have been slain. After a magical interlude in which they feast and drink joyously for eighty-seven years, first at Harddlech and then at the 'Assembly of the Wondrous Head' where they rejoice in the supernatural music of the birds of Rhiannon, their adventures end. These marvels are not lasting. When Heilyn son of Gwyn opens the door that looks out over Cornwall and Aber Henfelen, the comrades experience a forced re-entry into the world of human history, and their losses, by now almost a century in the past, are suddenly felt as if they were immediate (Thomson 1986, 15-18).

At this point, the Third Branch properly begins. Since Manawydan is one of the 'Three Ungrasping Chieftains' in Britain, he has no land or property of his own, and nowhere to go. Pryderi invites him to share his lordship over the seven cantrefs of Dyfed and to marry, if he wishes, his widowed mother Rhiannon. The latter is well into her second century if we examine the chronology of the Four Branches, but, as Pryderi points out, she is gracious, articulate, and still beautiful. ${ }^{3}$ Manawydan accepts this invitation, is well pleased by Rhiannon, and Manawydan, Rhiannon, Pryderi, and Pryderi's wife Cigfa begin to enjoy the life of aristocratic leisure that is appropriate for them. As the story proceeds, Manawydan and his friends are gradually stripped of rank and status. Their land is enchanted: the people who inhabit it and their crops and livestock vanish. Then the various attempts by Manawydan and his companions to support themselves by handicrafts fail. Finally, Pryderi and Rhiannon are abducted and only Manawydan and Cigfa are left in the deserted land. After a stint as a shoemaker, Manawydan finally returns to Dyfed and resorts to agriculture, but when he proposes to harvest the three crofts which he has sown, and thereby feed himself and Cigfa, he finds that mice have stripped them bare of wheat. In defending the final croft, Manawydan does succeed in capturing a slow-moving pregnant mouse and, apparently quite illogically, he prepares to hang her as a thief in accordance with the provisions of the law, in spite of the repeated protestations of his scandalized stepdaughter-in-law. 
Interpreting Manawydan fab Llŷr as a whole is beyond the scope of this article,${ }^{4}$ but one theme in this tale and indeed in all of the Four Branches is the contrast between the Otherworld in which women are often powerful and which is associated with the experiential values of love, sexuality, and aesthetic beauty (such as the 'birds of Rhiannon'), and the 'real' world in which men are dominant, social hierarchy is central, and war and personal violence are common. The Otherworld-or to be more precise, the lords and ladies who govern the Otherworld-are not necessarily wholly benevolent, but earthly military power is of no use against them. Earthly law, however-the rules by which men attempt to establish justice amongst men (and women)-seems to bind them and to curb their power. Manawydan is the great craftsman, skilled in a wide range of arts, and he waits patiently for his opportunity. Once he catches the pregnant mouse, he seems to know exactly what he is doing. He situates the gallows at Gorsedd Arberth, a site associated with the Otherworld, where he eventually negotiates an elaborate and binding contract with his Otherworldly adversary in which Pryderi and Rhiannon are freed, the land is restored, and Pryderi, Cigfa, Manawydan, and Rhiannon are returned to their position of wealth and privilege.

\section{Making the Punishment Fit the Crime, or, Constructing a Very Small Gallows}

The episode with which we are particularly concerned is the gallows scene:

Ac yna y kyrchwys ef orssed Arberth, a'r llygoden gantaw. A sengi dwy forch yn y lle uchaf ar yr orssed. Ac ual y byd y uelly, llyma y guelei yscolheic yn dyuot attaw, a hen dillat hydreul tlawt amdanaw. Ac neut oed seith mlyned kyn no hynny yr pan welsei ef na dyn na mil eithyr y pedwar dyn y buassynt y gyt-yny golles y deu.

'Arglwyd,' heb yr yscolheic, 'dyd da it.'

'Duw a rodo da it a grayssaw wrthyt,' heb ef. 'Pan doy di, yr yscolheic?' heb ef. 'Pan doaf, arglwyd, o Loygyr o ganu. A phaham y gouynhy di, arglwyd?' heb ef. 'Na weleis,' heb ef, 'neut seith mlyned un dyn yma onyt pedwar dyn diholedic, a thitheu yr awr honn.' (Ford 2000, 10).

Then he made for Gorsedd Arberth, taking the mouse with him, and he pushed two forks in the highest point of the mound. As he was doing this, he could see a cleric coming towards him, dressed in poor, threadbare, old clothes. And it was seven years since he had seen either man or beast, except for the four people who had been together until two of them disappeared. 
'Lord,' said the cleric, 'good day to you.'

'May God prosper you, and welcome,' said Manawydan. 'Where do you come from, cleric?' he said.

'I come, lord, from England where I have been singing. And why do you ask, lord?' he said. 'Because for the last seven years I have not seen a single person here, apart from four exiled people, and now yourself.' (Davies 2007, 43)

The scholar at this point asks Manawydan what he is doing, and, when he explains that he is hanging a mouse for theft, the scholar offers him a pound to redeem the mouse and prevent him from demeaning himself by executing such a trivial creature. Manawydan declines the offer and the scholar leaves. Manawydan continues to construct his miniature gallows, only to be interrupted by the arrival of a priest on horseback. After the standard pleasantries, the priest asks what Manawydan is doing, and offers an even greater sum than the cleric to redeem the mouse. Again, Manawydan rejects the proffered ransom and the priest leaves. As Manawydan ties the noose around the neck of the mouse, a third stranger approaches:

Sef a wnaeth ynteu, maglu y llinin am uynwgyl y llygoden. Ac ual yd oed yn y dyrchauael, llyma rwtter escob a welei, a'y swmereu a'y yniuer, a'r escop e hun yn kyrchu parth ac attaw. Sef a wnaeth ynteu, gohir ar y weith. 'Arglwyd escop,' heb ef, 'dy uendith.'

'Duw a rodo y uendith it,' heb ef. 'Pa ryw weith yd wyt ty yndaw?'

'Crogi lleidyr a geueis yn lledratta arnaf,' heb ef.

'Ponyt llygoden,' heb ynteu, 'a welaf i y'th law di?'

'Ie,' heb ynteu, 'a lleidyr uu hi arnaf i.'

'Ie,' heb ynteu, 'can doethwyf i ar diuetha y pryf hwnnw, mi a'y prynaf y genhyt; mi a rodaf seith punt it yrdaw a rac guelet gwr kyuurd a thi yn diuetha pryf mor dielw a hwnnw. Gollwng ef, a'r da a geffy ditheu.'

'Na ellynghaf, y rof a Duw,' heb ynteu.

'Kanys gollyngy yr hynny, mi a rodaf it pedeir punt ar ugeint o aryant parawt-a gellwng ef.'

'Na ellynghaf, dygaf y Duw uy ghyffes yr y gymeint arall,' heb ef.

'Canys collyghy yr hynny,' heb ef, 'mi a rodaf it a wely o uarch yn y maes hwnn a seith swmer yssyd yma ar y seith meirch y maent arnunt.' 'Na uynhaf, y rof a Duw,' heb ynteu. 
'Cany mynny hynny, gwna y guerth.'

'Gwnaf,' heb ynteu. 'Rydhau Riannon a Phryderi.'

'Ti a gehy hynny.'

'Na uynhaf, y rof a Duw.'

'Beth a uynhy ditheu?'

'Guaret yr hut a'r lledrith y ar seith cantref Dyuet.'

'Ti a geffy hynny heuyt; a gellwng y llygoden.'

'Na ellyngaf, y rof a Duw,' heb ef. 'Gwybot a uynhaf pwy yw y llygoden.'

'Wy gwreic i yw hi, a phy ny bei hynny nys dillyngwn.'

'Pa gyffuryf y doeth hi attaf i?'

'Y herwa,' heb ynteu. 'Miui yw Llwyt uab Kil Coet, a mi a dodeis yr hut ar seith cantref Dyuet, ac

y dial Guawl uab Clut o gedymdeithas ac ef y dodeis i yr hut. Ac ar Pryderi y dieleis i guare broch y ghot a Guawl uab Clut pan y gwnaeth Pwyll Penn Annwn, a hynny yn llys Eueyd Hen y gwnaeth o aghynghor. A guedy clybot dy uot yn kyuanhedu y wlat, y doeth uyn teulu attaf inheu ac y erchi eu rithyaw yn llygot y diua dy yd. Ac y doethant y nos gyntaf uyn teulu e hunein. A'r eil nos y doethant heuyt ac y diuayssant y dwy grofd. A'r tryded nos y doeth uy gwreic a gwraged y llys attaf y erchi im eu rithaw, ac y ritheis inheu. A beichawc oed hi, a phy na bei ueichawc hi, nis gordiwedut ti. A chanys bu, a'y dala hi, mi a rodaf Pryderi a Riannon it, ac a waredaf yr hut a'r lletrith y ar Dyuet. Minheu a uenegeis yti pwy yw hi, a gellwng hi.' (Ford 2000, 11-13)

Manawydan tied the string around the mouse's neck.

As he was hoisting it up, he could see a bishop's entourage and his baggage and his retinue, and the bishop himself approaching. So Manawydan postponed his work.

'Lord bishop,' he said, 'your blessing.'

'May God give you his blessing,' he said. 'What sort of work are you engaged in?'

'I'm hanging a thief I caught stealing from me,' he said.

'Isn't that a mouse I see in your hand?' he said.

'It is,' he said, 'and it stole from me.'

'Well,' said the bishop, 'since I have arrived just when you were about to destroy that creature, I will buy it from you. I will give you seven pounds for it, and rather than see a man of your status destroying such a worthless creature, let it go, and you shall have the money.'

'I will not let it go, between me and God,' he said.

'Since you will not let it go for that, I will give you twenty-four pounds in ready money to let it go.' 
'By my confession to God,' he said, 'I will not let it go for as much again.'

'Since you will not release the creature for that,' he said, 'I will give you every horse you can see on this plain, and the seven loads of baggage that are on the seven horses.'

'No, between me and God,' he said.

'Since you do not want that, name your price.'

'I will,' he said: 'the release of Rhiannon and Pryderi.'

'You shall have that.'

'That's not enough, between me and God.'

'What else do you want?'

'Remove the magic and enchantment from the seven cantrefs of Dyfed.'

'You shall have that too, now let the mouse go.'

'I will not, between me and God,' he said. 'I want to know who the mouse is.'

'She is my wife, and if she were not, I would not free her.'

'How did she come to me?'

'Stealing,' he said. 'I am Llwyd son of Cil Coed, and it is I who placed the enchantment on the seven cantrefs of Dyfed, and I did so to avenge Gwawl son of Clud, out of friendship for him; and I took revenge on Pryderi because Pwyll Pen Annwfn played Badger in the Bag with Gwawl son of Clud, and did that unwisely at the court of Hyfaidd Hen. And having heard that you were living in the land, my retinue came to me and asked me to turn them into mice so that they could destroy your corn [i.e. wheat]. The first night they came alone. And they came the second night too, and destroyed the two fields. But the third night my wife and the ladies of the court came to me and asked me to transform them too, and I did that. My wife was pregnant. And had she not been pregnant you would not have caught her. But since she was, and you did, I will give you Pryderi and Rhiannon, and I will remove the magic and enchantment from Dyfed. I have told you who she is, now let her go.' (Davies 2007, 44-45)

After discovering the identity of the mouse, Manawydan makes Llwyd agree that he will never again enchant Dyfed, nor take any vengeance on Manawydan, Rhiannon, or Pryderi. He refuses to release the mouse/wife until he sees Pryderi and Rhiannon, and when they arrive and the mouse goes free, Llwyd strikes her with his magic wand, freeing her from the enchantment. Dyfed is returned to its former state.

\section{Parallels and Commentary}


This episode has attracted some attention. Jackson cites several parallels. In a nineteenthcentury English folktale, a farmer disrupts elves who are absconding with his harvested wheat, and again in an Irish tale, witches transform themselves into beetles in order to steal wheat. They are caught, and must beg the farmer for their freedom (Jackson 1961, 104-105). A quatrain by Rhygyfarch ap Sulien (1056/57 - 1099), son of the bishop of Saint David's, entitled 'Carmen Ricemarch de messe infelici' (Rhygyfarch's poem on an unhappy harvest) bears some similarity to the episode in Manawydan:

Longa fluit pluuiis tempestas noxia nimbis, nam nequit in segites messor committere falces: quamuis ipse suis matures parcat aristis, turba tamen muris nescit iam parcere campis. (Lapidge 1973, 92)

The interminable rain, injurious (to the harvest) with its violent downfall pours down, for the reaper cannot commit his scythes to the crop. Although he himself spares his mature crop, none the less a host of mice refuse to spare the fields. (Lapidge 1973, 93)

Proinsias Mac Cana sees a connection between Rhygyfarch's quatrain and the Third Branch:

the setting is different, but the echo is clear: Rhygyfarch's host of mice, turba muris ... can hardly be disassociated from the other immense host, eliwlu y byd olygot, which consumed Manawydan's wheat... The coincidence is all the more remarkable because of the rarity, if not the uniqueness, of the motif on which the mice-episode in Manawydan is constructed: I have consulted several of my folklore colleagues on the matter, but so far they have not produced other instances. The fact that it is so rare might suggest that the Manawydan story is an imaginatively elaborated version of the more realistic incident versified by Rhygyfarch. (Mac Cana 1979, 179-80)

Patrick Sims-Williams disputes Mac Cana's suggestion for a connection between Rhygyfarch's poem and Manawydan, observing that 'the attack by vermin in Manawydan is a folk-tale motif' (Sims-Williams 2010, 260, n. 154, citing Jackson 1961). However, the parallels that Jackson offered did not, in fact, feature vermin stripping the fields per se, but elves and a pair of witches/beetles stealing wheat that had already been harvested. Rhygyfarch's quatrain is a 
closer match on that feature, but there is no indication that there is anything supernatural about Rhygyfarch's murine horde, and Otherworldly interference is surely a -if not thedefining feature of the episode.

As Sioned Davies observes, 'devastation of crops by supernatural creatures is a common motif' (Davies 2007, 239, n. 42), and medieval Irish literature features supernatural incursions against both the fields and the flocks of mortals. Two examples from the Middle Irish Acallam na Senórach (Colloquy of the ancients) will suffice to demonstrate the point:

Every year, three women of the Otherworld venture forth from the Cave of Cruachan in the shape of she-wolves, in order to devastate the flocks of sheep. Cass Corach beguiles them with his minstrelsy into doffing their dark wolf-skins, and he kills them with a single cast of his spear. (Stokes 1900, lines 7676-7717)

The kingdoms of West Munster are attacked every year at harvest time by three flocks of supernatural birds. The first flock carries off every ear in the cornfields, the second bears away all the fruits and nuts from the orchards, the third take fledglings, fawns, and children. Caílte waits for the birds in the cornfield, and when they arrive he casts a charm over them, causing the birds to fly away and war amongst themselves until all are dead. (Stokes 1900, lines 62706350)

While the incursion of the mice has been discussed, the other prominent features of this episode, the elaborate account of the near-hanging of the mouse and her redemption by her husband, have received less attention. To our knowledge, no convincing parallels or analogues have yet been suggested. For the reclaiming of marauding livestock there are some close parallels in medieval Welsh law: when a herd of swine damages the crop in a wheat field, the owner of the field keeps one of the offending sows until the same time on the next day, at which point the owner must come to redeem the sow for its legal value. If he should not, the owner of the field may keep the animal. The same procedure applies to a flock of sheep, and a hen caught in a flax garden was to be ransomed by its owner with a hen's egg (Wade-Evans 1909, 83-84; Jenkins 1986, 203-204). The public punishment of the fairy mouse in order to compel the return of Rhiannon and Pryderi from the Otherworld bears a resemblance to the widely-distributed folk motif of harming (or threatening to harm) a changeling in order to compel the return of the stolen child (F321.1.1.7, F321.1.1.6, F321.1.4.6, F321.1.4.5; Thompson 
1955-58; Robitaillié 2017), but while the aim is similar, the particular method of persuasion in Manawydan, namely, the threat of being hanged, is distinctive. ${ }^{5}$

However, there is an intriguing parallel to this episode in ballad tradition. The famous 'The Maid Freed from the Gallows' is an interesting and widely distributed ballad. ${ }^{6}$ There are hundreds of versions of it in a wide variety of languages and it is still current in the modern folk music canon. Lead Belly, Led Zeppelin, Bob Dylan, and Judy Collins have performed and recorded versions of it. One cannot quickly summarize a ballad that occurs in so many versions, and indeed in some versions it is not the maid but a masculine figure who is freed from the gallows. But given these caveats, a rough summary of the relevant version of the ballad is as follows. A maid or young woman (whether the maid in the ballad tradition is actually a virgin is debated) has committed an offense for which she will be hanged. The gallows are prepared and the executioner is ready to proceed. At this crucial moment an outsider, who is not directly involved in the maiden's crime, but who might free her, appears, and either offers or refuses to redeem the maid from execution. This intervention, however, delays the execution for a time and when the executioner is again ready, another figure appears who might free the maiden. He or she, however, does not or cannot prevent the execution, and the executioner yet again begins to proceed with the hanging. At this point, a third figure appears who is willing to pay the full price and redeems the maiden by paying whatever high ransom is demanded. This ballad summary could almost serve as a synopsis of the episode in Manawydan fab Llŷr.

The correspondences, however, are not exact. In some versions of the ballad the maiden's execution is interrupted by more than three potential rescuers: her father, mother, brother, and sister all arrive before she is to be executed and only when her lover or fiancé arrives is she set free. Again, while in Manawydan fab Llŷr all of those who intervene want Manawydan to spare the life of the lady who is transformed into a mouse, only the Otherworldly lord disguised as a bishop is capable of fulfilling all of Manawydan's demands. In the ballad tradition, the father, mother, and sister often come to watch the execution joyfully. In the Welsh text, a cheap payment is not going to dissuade Manawydan from executing the mouse; so the first two offers are unlikely to succeed. Still, the pattern of refusal and final rescue is broadly paralleled in the two texts. ${ }^{7}$

Despite these difficulties, both the Welsh text and the ballad are about a young woman freed from the gallows; her hopes of rescue are (at least) twice frustrated and finally are 
fulfilled, and the narrative unfolds in a dramatically empty landscape in which potential rescuers ride up one by one to the gallows from a distance. Rescue from the gallows is a relatively common motif, but a three- or four-part sequence leading to a reprieve is not.

Explaining and defining the connection between the Welsh text and the traditional ballad is complicated and necessarily speculative. To begin with, the Four Branches of the Mabinogi as we have them are extant in two fourteenth-century manuscripts; two further fragments, from the Second and Third Branches respectively, are found in Peniarth MS 6 (mid thirteenth century). However, it is widely agreed that aspects of the Mabinogi are very old indeed, and that there are elements of it that may date back to pre-Christian British antiquity. The ballad, by contrast, is not attested before the very end of the seventeenth century in continental Europe or the eighteenth century in Britain. ${ }^{8}$ We thus have a temporal gap of approximately four or five hundred years and it is also true that there are no versions of this ballad in Welsh.

The ballad itself has puzzled specialists. Part of the definition of a ballad is that it is a narrative poem and 'The Maid Freed from the Gallows' reads like a fragment of a longer narrative. What did the maid do to merit the death penalty? ${ }^{9}$ Why are all her blood relatives, including her mother and father, so angry that they want to see her hanged? Given these questions, Child decided that all of the English and Scots versions of the ballad were in fragmentary form and cited a Sicilian version, in which the heroine is captured by pirates and eventually redeemed by her husband, as a more complete and coherent version of the story (Child 2001, 430-39). There are, however, significant narratological problems with the Sicilian ballad: as Child noted, the narrative of even the full version is not wholly coherent, and there are eleven versions of 'The Maid Freed from the Gallows' preserved in English and Scots, none of which elaborates the story significantly. Child also mentions that the ballad is echoed in a children's game and this detail is perhaps important. Children's games often re-enact social rituals and one can certainly perceive social significance in 'The Maid Freed from the Gallows'. In medieval, early modern, and to some degree even modern times, one of the great transitions in a young woman's life occurs when she leaves the protection and familiarity of her blood family and moves into a new life with her husband or lover. The ballad dramatizes this transition in that the heroine's blood family rejects her and at the last moment, when hope seems lost, it is her 'true-love' who rescues her from the gallows. Marriage, like death, is a rite of passage, and the bride's separation from her natal family and integration into her husband's 
family may be seen as a sort of social death and rebirth. In numerous cultures there is a genre of bridal lament that is modelled on or related to funeral lament (Johnson 1988; Dwyer 2008), and in some such traditions the bride addresses each of her kin in turn, lamenting their complicity in the arrangement of the marriage (Virtanen and Dubois 2000).

This reading of the ballad, however convincing it may seem, does not in itself solve the problem of the cultural, linguistic, and temporal gap between 'The Maid Freed from the Gallows' and Manawydan fab Llŷr, but it does suggest why some version of the narrative of the ballad, or a folktale related to the ballad, might have been current long before the versions we have were recorded. The problem of the antiquity of the traditional English and Scots popular ballad is much debated. Child himself seems to have thought that the oldest and bestpreserved ballads were (relatively) old themselves and that they were repositories of much older lore (Brown 2011, 234-42). Modern ballad scholars are more sceptical than Child apparently was (it must be remembered that he never completed the portion of The English and Scots Popular Ballads in which he would have addressed these issues directly), but the currency of striking parallels between relatively modern folktales and ballads and such genres as Middle High German romance and epic, Old French romance and chansons de geste, and the Icelandic family sagas is widely accepted. ${ }^{10}$ To argue that an episode in a Welsh prose narrative which probably dates to the twelfth century ${ }^{11}$ is paralleled in 'modern' ballad tradition is no more remarkable than to point out that twelfth-century Old French verse narratives such as the Lais of Marie de France or the romances of Chrétien de Troyes offer many parallels to more recent folktales and ballads. The precise relationship between the various texts in which such parallels and motifs appear cannot always (or even often) be identified, and in many cases we are no doubt seeing the outcome of free-floating motifs being plucked from folk tradition, rather than influence from one literary text upon another; that said, in this particular case it is reasonable to consider the possibility of influence of a proto-form of the ballad on the Middle Welsh narrative.

If one defines 'The Maid Freed from the Gallows' loosely as a narrative poem, some other narrative poem or song, folktale, or children's chant embodying the content of the ballad could have been current in the literary or folk cultural milieu of the Welsh prose text. We would speculate that Manawydan fab Llyr parodies this narrative and to that degree is dependent upon it. The Third Branch of the Mabinogi is a comedy, both in the technical literary sense that the story ends happily, and also in that there is a great deal of material in 
the story which seems at least potentially comic. Great Welsh lords and warriors are reduced to being craftsmen to support themselves, and must flee English towns three times to escape the anger and jealousy of shoemakers and similar figures. Pryderi and Rhiannon are somehow stuck to a bowl when they venture into the Otherworldly castle which has suddenly appeared during the enchantment of Dyfed, and during their stay in the Otherworld they are used as props on which to hang 'gate hammers' and 'horse collars' respectively. It is of course hard to say how funny the original Welsh audience would have found these elements of the story, but it does seem clear that in these episodes the characters are presented as undignified, and to that extent comic. The proposed hanging of the pregnant mouse is arguably also intended to be amusing. ${ }^{12}$ Medieval Welsh culture is very alien in some ways, but the absurdity of dealing with a pregnant mouse as if she were a human malefactor and threatening to punish her with formal execution is manifest.

We would argue that the (proposed) execution of the enchanted mouse in Manawydan fab Llŷr can be situated and to some degree explained in relationship to the "Maid Freed from the Gallows' ballad family and related materials. The relationship of any two related stories, or story episodes as in this instance, can raise complex literary historical and critical questions, but it may be argued that the comparison of stories whose relationship is distant can still be illuminating and interesting. Grettir's fight with the trolls at Sandhaugar and Beowulf's fight with Grendel and his mother are separated by language, by genre, and by at the least three hundred and fifty or four hundred years (assuming a late date for Beowulf and by more than that if early daters such as Robert Fulk and Leonard Neidorf are right ${ }^{13}$ ), but generations of scholars and critics have accepted that there is such a relationship and found comparing these parallel stories interesting and illuminating.

If this argument seems cogent, some version of the narrative of 'The Maid Freed from the Gallows', in some popular form, was current long before the eighteenth century in Britain, in some language and possibly in Middle Welsh. Again, while the Four Branches of the Mabinogi are polished courtly narratives in the form in which we have them, the author or authors of these tales drew on folklore in a variety of ways, and the hanging scene in Manawydan fab Llŷr can be situated and understood better in this context. More importantly, perhaps, the two texts illuminate each other literarily. The parallels and contrast between the dark drama of 'The Maid Freed from the Gallows' and the absurd humour of Manawydan's use of the law of theft to free himself and his friends from hostile enchantment illuminate each 
other. While an enchanted pregnant mouse and a maiden threatened with death on the gallows may not seem to have much in common, we as readers or auditors are happy to see them both freed. The ending of the Third Branch subverts the sympathies of the ballad: the reader identifies both with Manawydan, the protagonist of the narrative, and the pregnant mouse/lady. Happy endings, particularly if they affirm justice, make for good stories.

\section{Appendix}

'The Maid Freed from the Gallows' (Child ballad no. 95, version A)

1 'GOOD Lord Judge, and sweet Lord Judge, Peace for a little while!

Methinks I see my own father, Come riding by the stile.

2 'Oh father, oh father, a little of your gold, And likewise of your fee!

To keep my body from yonder grave.

And my neck from the gallows-tree'.

3 'None of my gold now you shall have,

Nor likewise of my fee;

For I am come to see you hangd, And hanged you shall be'.

4 'Oh good Lord Judge, and sweet Lord Judge, Peace for a little while! Methinks I see my own mother, Come riding by the stile. ${ }^{14}$

3 'Oh mother, oh mother, a little of your gold. And likewise of your fee, To keep my body from yonder grave, 
And my neck from the gallows-tree!'

8 'None of my gold now shall you have.

Nor likewise of my fee;

For I am come to see you hangd,

And hanged you shall be'.

7 'Oh good Lord Judge, and sweet Lord Judge,

Peace for a little while!

Methinks I see my own brother,

Come riding by the stile.

8 'Oh brother, oh brother, a little of your gold,

And likewise of your fee.

To keep my body from yonder grave.

And my neck from the gallows-tree !'

9 'None of my gold now shall you have.

Nor likewise of my fee;

For I am come to see you hangd,

And hanged you shall be'.

10 Oh good Lord Judge, and sweet Lord Judge,

Peace for a little while!

Methinks I see my own sister.

Come riding by the stile.

11 'Oh sister, oh sister, a little of your gold.

And likewise of your fee.

To keep my body from yonder grave,

And my neck from the gallows-tree!' 
12 'None of my gold now shall you have,

Nor likewise of my fee;

For I am come to see you hangd.

And hanged you shall be'.

13 'Oh good Lord Judge, and sweet Lord Judge,

Peace for a little while!

Methinks I see my own true-love,

Come riding by the stile.

14 'Oh true-love, oh true-love, a little of your gold,

And likewise of your fee.

To save my body from yonder grave.

And my neck from the gallows-tree'.

15 'Some of my gold now you shall have,

And likewise of my fee.

For I am come to see you saved.

And saved you shall be'. (Child 2001, vol. 2: 239-40)

\section{Notes}

${ }^{14}[$ W] hat chiefly strikes the Celticist about modern folklore studies, and particularly about theories of the origin and diffusion of the folktale, is that most folklorists seem almost totally ignorant of the fact that so many of their motifs are to be found in Celtic literature centuries before they appear anywhere else' (Jackson 1954, 549).

${ }^{2}$ The Four Branches of the Mabinogi are four linked Middle Welsh prose narratives, set during a legendary ancient British past. The First and Third Branches are focused on Dyfed in southern Wales, and much of the action in the Second and Fourth Branches is localized to Gwynedd and Anglesey in the north; how, where, and when the tales were written, or came together to form a cohesive group, has been much debated.

${ }^{3}$ Rhiannon's longevity is explained by that fact that she comes from the Otherworld. Her strong equine affinities in the First Branch-she first appears riding a magical horse; she is punished by having to carry visitors to the court of Dyfed on her back, like a horse; and her son is abducted on the night of his birth (the supernaturally significant Calan Mai 'May Day') along with a foal-have long prompted 
scholars to speculate that she was originally a horse goddess, perhaps to be identified with the Gaulish goddess Epona, who was popular amongst Roman cavalry units. For a relatively recent treatment of Rhiannon, see Hemming (1998).

${ }^{4}$ For thematic studies of Manawydan uab Llyr, see Ford (1981), Koch (1987), and McKenna (1999).

${ }^{5}$ Patrick K. Ford views the confining of the mouse to Manawydan's glove as a doubling of Pwyll's tricking of his rival Gwawl into a sack where he is promptly and viciously beaten as the "badger in the bag'. Broch is the term used for the badger in the First and Third Branches, but Ford points out that another term for the animal in Welsh is pryf llwyd 'grey/brown creature', and states that when 'she is captured, the pregnant mouse is, as it were, Mrs Llwyd. There is an unabashed resemblance between the two animals at the moment they are imprisoned: both are animals (literally or functionally), both are in bags, one may be described as llwyd, the other actually so named' (Ford 1981, 124).

${ }^{6}$ An important study of the ballad is Long (1971).

${ }^{7}$ For a discussion of a narrative elaboration of the 'Maid Freed from the Gallows' tradition in the context of American folk literature, which is similar in some ways to the Welsh narrative, see Urcia $(1966,467)$.

${ }^{8}$ The oldest English language version (Child no. 95, A; reprinted above) was communicated to Bishop Percy on 7 April 1770 (Child 2001, 439); the earliest European version-from Iceland-is dated to 1700 (Long 1971, 109).

${ }^{9}$ Interestingly, in some English/Scots versions of the ballad, she has lost her golden ball, a detail which is reminiscent of the Grimms' 'Der Froschkönig' (The Frog King) in which the princess loses her golden ball in a deep spring, an event that initiates the narrative which culminates in her marriage to the prince. Marriage, or the erotic relationship outside the limits of the 'blood' family, is an important theme in 'The Maid Freed from the Gallows' ballad tradition.

${ }^{10}$ For examples see Guerreau-Jalabert (1992); see also Motif-Index of German Secular Narratives (2009).

${ }^{11}$ The Four Branches are found in their entirety in two fourteenth-century manuscripts, the White Book of Rhydderch and the Red Book of Hergest, and fragments of the Second and Third Branches are found in Peniarth 6, a thirteenth-century manuscript. It is generally thought that the Four Branches were written in, or existed in some form by, the twelfth century (Roberts 2001; Sims-Williams 2001). However, the scene under consideration in this essay is not found in the Peniarth 6 fragment, and it is possible that it was a later addition to the text.

${ }^{12}$ Note that Manawydan is told four times by other characters in the narrative that executing a mouse is inappropriate and silly and that one of the characters who so warns him is his friend and stepdaughter-in-law Cigfa. The apparent absurdity of Manawydan's actions is thus commented upon in the original tale, which supports the contention that this episode is comic to some degree.

${ }^{13}$ See Neidorf (2014) for references to the literature on the debate.

\section{References Cited}


Brown, Mary Ellen._Child's Unfinished Masterpiece: The English and Scottish Popular Ballads. Urbana, Chicago, and Springfield: University of Illinois Press, 2011.

Child, Francis James, ed. The English and Scottish Popular Ballads. 5 vols. Corrected 2nd edition by Mark F. Heiman and Laura Saxton Heiman. Northfield, MN: Loomis House Press, 2001 - 2005. First published 1883-98.

Davies, Sioned. The Mabinogion. Oxford: Oxford University Press, 2007.

Dwyer, Arienne M. 'Bridal Laments in the Turkic World: A Casualty of Modernity?' In Groups, Ideologies and Discourses: Glimpses of the Turkish Speaking World, edited by Christoph Herzog and Barbara Pusch, 131-43. Würzburg: Ergon, 2008.

Ford, Patrick K. 'Prolegomena to a Reading of the Mabinogi: 'Pwyll' and 'Manawydan”'. Studia Celtica 16 (1981): 110-25.

------, ed. Manawydan uab Llyr: Text from the Diplomatic Edition of the White Book of Rhydderch, by J. Gwenogvryn Evans. Belmont, MA: Ford \& Bailie, 2000.

Guerreau-Jalabert, Anita. Index des Motifs Narratifs dans les Romans Arthuriens Francais en Vers (XIIe-XIIIe Siècles [Motif index of French Arthurian verse romances (XIIth XIIIth centuries)]. Publications Romanes et Françaises 202. Geneva: Libraire Droz, 1992.

Hemming, Jessica. 'Reflections on Rhiannon and the Horse Episodes in Pwyll'. Western Folklore 57 (1998): 19-40.

Jackson, Kenneth Hurlstone. Review of Motif-Index of Early Irish Literature by Tom Peete Cross. Speculum 29 (1954): 548-51.

------. The International Popular Tale and Early Welsh Tradition. Cardiff: University of Wales Press, 1961.

Jenkins, Dafydd. ed. and trans. The Law of Hywel Dda: Law Texts from Medieval Wales. Llandysul: Gomer Press, 1986.

Johnson, Elizabeth L. 'Grieving for the Dead, Grieving for the Living: Funeral Laments of Hakka Women'. In Death Ritual in Late Imperial Modern China, edited by James L. Watson and Evelyn S. Rawski, 135-63. Berkeley: University of California Press, 1988. 
Keefer, Sarah Larratt. 'The Lost Tale of Dylan in the Fourth Branch of the Mabinogi'. Studia Celtica 24 (1989): 26-37. Reprinted in The Mabinogi: A Book of Essays, edited by C. W. Sullivan III, 79-98. New York: Garland, 1996.

Koch, John T. 'A Welsh Window on the Iron Age: Manawydan, Mandubracios'. Cambridge Medieval Celtic Studies 14 (1987): 17-52.

Lapidge, Michael. ‘The Welsh-Latin Poetry of Sulien’s Family’. Studia Celtica 8 (1973): 68-106.

Long, Eleanor R. 'The Maid' and 'The Hangman': Myth and Tradition in a Popular Ballad. Berkeley: University of California Press, 1971.

Mac Cana, Proinsias. 'Notes on the “Abnormal Sentence”'. Studia Celtica 14 (1979): 174-87.

McKenna, Catherine. 'Learning Lordship: The Education of Manawydan'. In Ildánach, Ildírech: A Festschrift for Proinsias MacCana, edited by John Carey, John T. Koch, and Pierre-Yves Lambert, 101-20. Aberystwyth: Celtic Studies Publications, 1999.

Motif-Index of German Secular Narratives from the Beginning to 1400, 6 vols. Edited by the Austrian Academy of Sciences, Helmut Birkhan, Karin Lichtblau, Christa Tuczay, in collaboration with Ulrike Hirhager and Rainer Sigl. Berlin and Boston: De Gruyter, 2009.

Neidorf, Leonard, ed. The Dating of Beowulf: A Reassessment. Anglo Saxon Studies 24._Cambridge Boydell \& Brewer, 2014.

Roberts, Brynley F. 'Where were the Four Branches of the Mabinogi Written?' In The Individual in Celtic Literature, CSANA Yearbook 1, edited by Joseph Falaky Nagy, 61-73. Dublin: Four Courts Press 2001.

Robitaillié, Audrey. 'The Bagpipe Player in the Cradle, an Irish Changeling Motif. Folklore 128, no. 4 (December 2017): 376-95.

Sims-Williams, Patrick. 'Clas Beuno and the Four Branches of the Mabinogi'. In 150 Jahre 'Mabinogion': Deutch-Walische Kulturbeziehungen [150 years of the 'Mabinogion': German-Welsh cultural relations], edited by Bernard Maier and Stefan Zimmer, with Christine Bakte, 111-27. Tübingen: Walter de Gruyter, 2001.

------. Irish Influence on Medieval Welsh Literature. Oxford: Oxford University Press, 2010. 
Stokes, Whitley, ed. and trans. Acallamh na Senórach [The colloquy of the ancients]. Vol. 1 of Irische Texte mit Wörterbuch [Irish texts with glossary], series 4, edited by Whitley Stokes and Ernst Windisch. Leipzig: Hirzel, 1900.

Thompson, Stith. Motif-Index of Folk Literature. Rev. and enl. edn. Bloomington: Indiana University Press, 1955-58.

Thomson, Derick S., ed. Branwen Uerch Lyr: the Second of the Four Branches of the Mabinogi, edited from the White Book of Rhydderch, with Variants from the Red Book of Hergest and from Peniarth 6. Dublin: DIAS, 1986.

Urcia, Ingeborg. 'The Gallows and the Golden Ball: An Analysis of "The Maid Freed from the Gallows" (Child 95)'. Journal of American Folklore 79 (1966): 463-68.

Virtanen, Leea, and Thomas A. Dubois. An Anthology of Finnish Folklore. Studia Fennica Folkloristica 9. Helsinki: Finnish Literature Society \& University of Washington Press, 2000.

Wade-Evans, A. W., ed. and trans. Welsh Medieval Law. Oxford: Clarendon Press, 1909.

Welsh, Andrew. 'The Traditional Narrative Motifs of The Four Branches of the Mabinogi'. Cambridge Medieval Celtic Studies 15 (1988): 51-62.

\section{Biographical Notes}

Thomas D. Hill received his BA from Harvard University in 1961, his MA from the University of Illinois in 1963, and his PhD from Cornell University in 1967. He has published papers, edited, and written books in the field of Old English, and published papers on Middle English, Old Norse-Icelandic, Old French, and on various other medieval literary texts. He has taught Old and Middle English and other medieval subjects at Cornell University since 1967.

Kristen Mills received her BA from Cornell University in 2005, and her MA and PhD from the University of Toronto's Centre for Medieval Studies in 2006 and 2012, respectively. She is currently a Postdoctoral Research Fellow at the University of Oslo; she previously held a Mellon Postdoctoral Fellowship at Haverford College. She has published papers on Old Norse-Icelandic, Old and Middle Irish, and Old English literature. 